\title{
AKTIVITAS ANTIMIKROBA TERIPANG KASUR (Stichopus vastus Sluiter) DARI PERAIRAN NATUNA KEPULAUAN RIAU
}

\author{
Mery Sukmiwati ${ }^{\star 1}$, Andarini Diharmi ${ }^{1}$, Enda Mora ${ }^{2}$, Emma Susanti ${ }^{2}$ \\ ${ }^{1}$ Departemen Teknologi Hasil Perikanan, Fakultas Perikanan dan Kelautan Universitas Riau, \\ ${ }^{2}$ Sekolah Tinggi Farmasi Riau \\ Jalan HR. Subrantas KM.12,5 Simpang Baru, Tampan, Kota Pekanbaru Riau, 28293. \\ Telepon: 0761-6327/63274. \\ *Korespondensi: merysarmin@yahoo.com \\ Diterima: 23 Agustus 2018/ Disetujui: 24 Agustus 2018
}

Cara sitasi: Sukmiwati M, Diharmi A, Mora E, Susanti E. 2018. Aktivitas antimikroba teripang kasur (Stichopus vastus Sluiter) dari Perairan Natuna Kepulauan Riau. Jurnal Pengolahan Hasil Perikanan Indonesia. 21(2): 328-335.

\begin{abstract}
Abstrak
Teripang merupakan salah satu sumber daya perairan yang belum termanfaatkan secara optimal. Hewan laut ini mengadung komponen bioaktif yang cukup potensial, oleh karena itu teripang dapat dimanfaatkan sebagai salah satu alternatif oleh industri farmasi sebagai bahan baku obat dan industri pengolahan hasil perikanan. Penelitian ini bertujuan untuk menentukan aktivitas antibakteri dan antijamur berdasarkan zona hambat terhadap Staphylococcus aureus, Staphylococcus epidermilis, Escherichia coli, Pseudomonas aeruginosa dan antijamur terhadap Candida albicans, Trihopyton mentagrophytes. Metode penelitian terdiri dari ekstraksi dengan metanol, uji fitokimia, fraksinasi, uji aktivitas antibakteri dan antijamur dengan metode difusi, serta komatografi vakum cair. Eksperimen dilakukan dengan 3 kali ulangan dan analisis secara deskriptif. Hasil penelitian menunjukkan ekstrak teripang terdeteksi mengandung komponen saponin, terpenoid dan steroid. Diameter zona hambat ekstrak teripang terhadap 4 spesies bakteri berkisar dari 10,33-12,26 mm, antijamur C. albicans $9,77 \mathrm{~mm}$ dan T. mentagropytes $9,12 \mathrm{~mm}$. Hasil kromatografi vakum cair berbagai kosentrasi menunjukkan aktivitas maksimum antibakteri dan antijamur yang memiliki aktivitas interaksi tertinggi terhadap S. epidermilis dan jamur C. albicans.
\end{abstract}

Kata kunci: antibakteri, antijamur, ekstrak teripang, fraksinasi, komponen aktif

\section{Amtimicrobial Activity of Sea Cucumber (Stichopus vastus Sluiter) from Natuna Coastal Sea of Riau Islands}

\begin{abstract}
Sea cucumber is one of the waters bioresources that have not been utilized optimally. These marine animals contain potentially bioactive compounds, therefore it can be used as an alternative by the pharmaceutical industry as a raw material of medicinal and fishery products processing industries. This study was aimed to determine the antibacterial and antifungal activity against Staphylococcus aureus, Staphylococcus epidermilis, Escherichia coli, Pseudomonas aeruginosa and Candida albican as well as Trihopyton mentagrophytes. The method comprise of antibacterial and antifungal activity test with diffusion method. Experiments were carried out with 3 replications and analyzed descriptively. The results showed that methanol extract of sea cucumber contained saponins, terpenoids and steroids. The diameter of methanol extracts inhibitory zone of $S$. vastus on 4 species of bacteria ranged from 10.33 to $12.26 \mathrm{~mm}$ and 2 species of fungal namely: C. albicans $9.77 \mathrm{~mm}$ and T. Mentagropytes $9.12 \mathrm{~mm}$. The results of various concentrations of liquid chromatography vacuum showed the maximum antibacterial and antifungal activity which had the highest interaction activity against $S$. epidermilis and C. albicans.
\end{abstract}

Keywords : antibacterial, antifungal, bioactive compound, sea cucumber, sea cucumber extract 


\section{PENDAHULUAN}

Komponen-komponen baru yang bersifat antimikrobadarihasilmetabolismemerupakan salah satu upaya dalam pengembangan obat antibiotik. Kelompok komponen tersebut meliputi $\beta$-laktam (penisilin) sefalosporin dan karbapenem (Von Nussbaum et al. 2006). Kemampuan komponen-komponen antibiotik mulai berangsur-angsur menurun dengan berjalannya waktu, hal tersebut disebabkan mikroorganisme yang menjadi target ikut mengembangkan kekebalan terhadap komponen-komponen tersebut. Kloramfenikol ditemukan pada pertengahan abad 19, sebagai produk kimia dari organisme. Streptomyces venezuaelae, komponen kimia tersebut mampu menurunkan tingkat kematian akibat penyakit tipes (thyphoid) (Van der Bergh et al. 1999), akhir-akhir ini bakteri penyebab demam tifoid telah mengalami resistensi terhadap antibiotik tersebut (Ivanov 1998). Gejala yang sama juga ditemukan pada obat-obat antibiotik yang lain, oleh karena itu perlu dilakukan pencarian komponen-komponen antimikroba baru dan sekaligus pengembangannya, karena sampai saat ini penanggulangan penyakit yang disebabkan oleh bakteri masih mengandalkan antibiotik sintetik, sehingga akan menimbulkan kekhawatiran munculnya strain bakteri baru yang resisten terhadap antibiotik (Tirtodiharjo 2011).

Penelitian mengenai pencarian sumber antibakteri dari bahan baku hasil perairan telah banyak dilakukan, antara lain antibakteri dari kerang bakau (Geloina coaxans) terhadap Vibrio parahaemolyticus (Weliyadi et al. 2018), hidrolisat protein hasil fermentasi telur ikan cakalang (Aditia et al. 2018), ekstrak daun bakau hitam (Rhizophora mucronata) terhadap bakteri penyebab diare (Tarman et al. 2013). Skeletonema costatum terhadap bakteri Vibrio sp. (Setyaningsih et al. 2006), nanokitosan pada edible coating terhadap bakteri E. coli dan S. aureus (Rochima et al. 2018). Ekstrak etil asetat biji teratai Nymphaea pubescens Willd terhadap bakteri E. coli $S$. typhimurium (Fitrial 2011), kitosan mikrokristalin terhadap bakteri pada rongga mulut (Ibrahim et al.
2012), serta Penicillium sp. R1M yang diisolasi dari mangrove Sonneratia caseolaris terhadap bakteri E. coli dan S. aureus (Prihanto 2012).

Teripang atau timun laut adalah organisme laut dari phylum Echinodermata, merupakan salah satu sumber daya perairan yang belum dimanfaatkan secara optimal. Teripang kasur memiliki kandungan protein dan kolagen yang sangat tinggi, selain itu teripang mengandung mineral, mukopolisakarida, glucosaninoglycans, omega-3, 6, dan 9, asam amino, chondroitin, steroid (Jahawar et al. 2002; Meydia et al. 2016; Tarman 2007).

Beberapa hasil penelitian lainnya membuktikan bahwa komponen steroid pada teripang Cucumaria frondosa mempunyai aktifitas antibakteri (Haug et al. 2002 ), aktifitas antijamur pada teripang spesies Psoulus patagonicus (Murray et al. 2001). Kandungan antibakteri dan antifungi pada teripang dapat digunakan sebagai bahan baku perawatan kulit (Aminin 2001).

Komponen bioaktif yang terdapat pada teripang Holothuria sp. beberapa di antarnaya dapat berfungsi sebagai antibakteri dan antifungi. Kaswandi et al. (2000) melaporkan bahwa bahan aktif dari teripang H. tubolos dapat menghambat pertumbuhan Saccharomycescerevisiae. Isolasi masingmasing komponen pada Stichopus vastus perlu dilakukan dalam upaya mencari alternatif kandidat obat baru yang bersifat antibiotik sebagai antibakteri dan antijamur. Penelitian ini bertujuan untuk menentukan aktivitas antibakteri dan antijamur dari teripang kasur, berdasarkan zona hambat terhadap bakteri Staphylococcus aureus, Staphylococcus epidermilis, Escherichiacoli, Pseudomonas aeruginosa, dan jamur Candida albicans, Trihopyton mentagrophytes.

\section{BAHAN DAN METODE Bahan dan Alat}

Sampel teripang S. Vastus dengan ukuran panjang berkisar antara $122 \mathrm{~mm}-280 \mathrm{~mm}$ dengan panjang rata-rata $(200,11 \pm 42,88 \mathrm{~mm})$ dan berat berkisar 161-546 g, berasal dari Perairan Natuna Kepulauan Riau. Bahan kimia yang digunakan dalam penelitian ini adalah metanol (p.a E.Merck), n-heksan (p.a Merck, Jerman), etil asetat (p.a Merck, Jerman), 
butanol (p.a Merck, Jerman), DMSO (Merck, Jerman), nutrient agar (NA), potato dextrose agar (PDA), $\mathrm{NaCl}$ fisiologis $(0,85 \% \mathrm{NaCl})$. Kultur murni S. aureus, S. epidermilis, E. coli, $P$. aeruginosa, $C$. albicans, T.mentagropytes dari Laboratorium Pusat Antar Universitas (PAU) Universitas Gadjah Mada.

Alat-alat yang digunakan pada penelitian ini antara lain: rotary vacuum evaporator (Heidolph WB 2000), inkubator (Isuzu Incubator SSJ-115 Japan), cawan petri (Pyrex), mikropipet (Merck Thermo Scintific), peralatan gelas (Iwaki Pyrex), oven (Yamato DV 41), heater (Merck Thermoline), blender (Merek PHILIP HR2108).

\section{Metode Penelitian}

Penelitian ini dilakukan melalui beberapa tahap, yaitu preparasi bahan baku, uji komponen aktif, penentuan konsentrasi hambat minumum (KHM) pada fraksi yang berbeda, dan penentuan fraksi aktif melalui uji KLT dan Liquid chromatograhy vacuum terhadap aktivitas bakteri. Eksperimen dilakukan dengan 3 kali ulangan dan dianalisis secara deskriptif.

\section{Ekstraksi dan fraksinasi}

Ekstraksi dilakukan terhadap teripang S. vastus dengan metode maserasi (Harbone 2006). Teripang yang sudah dirajang halus sebanyak $1.000 \mathrm{~g}$ dimeserasi dengan pelarut metanol selama 3 hari dengan 3 kali ulangan dengan perbandingan bahan dan pelarut 1:3. Maserat yang didapat dipekatkan dengan vacuum rotary evaporator pada suhu $40^{\circ} \mathrm{C}$, hingga diperoleh ekstrak kasar, yang kemudian diuji fitokimia meliputi komponen flavonoid, saponin, tannin, alkaloid dan triterpenoid.

\section{Pemurnian komponen bioaktif $S$. vastus}

Pemurnian komponen bioaktif S.vastus dilakukan melalui fraksinasi ekstrak metanol mengunakan pelarut $n$-heksan, etil asetat, butanol dan air. Fraksi diuapkan dengan rotary evaporator hingga diperoleh fraksi kental, kemudian diuji antibakteri dan antijamur. Fraksi dengan aktivitas antibakteri terbaik dilakukan uji kromatografi vacum cair menggunakan metode (Boyer 1993).

\section{Uji aktivitas antibakteri dan antijamur}

Uji aktivitas antibakteri dan antijamur dilakukan melalui metodedifusi yang mengacu pada penelitian Moorthy et al. (2007). Mikroba uji yang digunakan S. aureus, S. epidermilis, E. coli, P. aeruginosa, yang diperoleh dari Universitas Gajah Mada. Sampel suspensi mikroba sebanyak $100 \mu \mathrm{L}$ dipipet dan dimasukkan ke dalam cawan petri steril, media NA ditambahkan sebanyak 12 $\mathrm{mL}$, kemudian cawan petri digoyang hingga homogen dan biarkan memadat. Kontrol positif menggunakan kroramfenikol larutan uji sebanyak $10 \mu \mathrm{L}$ diteteskan pada kertas cakram steril, diinkubasi selama 18-24 jam pada suhu $37^{\circ} \mathrm{C}$.

Uji antijamur serupa dengan metode antibakteri melalui metode difusi, jenis jamur yang digunakan C. albicans dan T. mentagrophytes. Media yang digunakan adalah potato dextrose agar (PDA), inkubasi untuk antijamur selama 3-5 hari pada suhu kamar $\left(25-27^{\circ} \mathrm{C}\right)$. Kontrol positif menggunakan nistatin $0,3 \%$ sebanyak $(30 \mu \mathrm{L} /$ cakram). Pertumbuhan mikroba diamati dan diukur diameter hambatnya.

\section{HASIL DAN PEMBAHASAN Komponen Aktif Ekstrak Teripang Stichopus vastus}

Komponen aktif ekstrak kental metanol teripang disajikan pada Tabel 1. Hasil kandungan metabolik sekunder dari ekstrak metanol teripang kasur menunjukkan bahwa teripang kasur mengadung komponen saponin, terpenoid dan steroid. Hashimoto (1979) menyatakan bahwa komponen toksin yang terdapat pada teripang dikenal sebagai saponin, yaitu komponen yang komplek terdiri dari gula dan steroid atau triterpenoid. Saponin merupakan komponen aktif dengan sifatnya yang khas menyerupai sabun, menimbulkan busa jika dikocok dalam air dan saponin dapat menghancurkan butir sel darah merah lewat reaksi haemolisis (Robinson 1995).

Buih yang terbentuk pada uji kandungan saponin menunjukkan bahwa saponin bereaksi dengan air yang merupakan komponen polar. Saponin berkontribusi sebagai antijamur 
Tabel 1 Hasil kandungan metabolik sekunder ekstrak metanol teripang (Table Secondary metabolites methanol extract of sea cucumber

\begin{tabular}{lccc}
\hline $\begin{array}{c}\text { Komponen/Bioactive } \\
\text { compounds }\end{array}$ & Pereaksi/Reagen & Keterangan/Infomation & Hasil/Result \\
\hline Alkaloid & Meyer & Tidak terbentuk endapan putih & $(-)$ \\
& Dragendorff & Putih - orange & $(-)$ \\
Fenolik & $\mathrm{FeCl}_{3} 1 \%$ & Tidak terbentuk warna biru & $(-)$ \\
Flavonoid & Sianidin test & Tidak terbentuk warna merah & $(-)$ \\
Saponin & $\mathrm{H}_{2} \mathrm{O}$ & Terbentuk busa & $(+)$ \\
Terpenoid & Liberman- Burchad & Terbentuk warna kecolatan & $(+)$ \\
\hline
\end{tabular}

dengan mekanisme menurunkan tegangan permukaan membran sterol dari dinding sel C. albicans, sehingga permeabilitasnya meningkat. Permeabilitas yang meningkat mengakibatkan cairan intraseluler yang lebih pekat tertarik keluar sel sehingga nutrisi, zat-zat metabolisme, enzim, protein dalam sel keluar dan jamur mengalami kematian. Saponin merupakan golongan komponen yang dapat menghambat atau membunuh mikroba dengan cara berinteraksi dengan membran sterol. Efek utama saponin terhadap mikroba adalah adanya pelepasan protein dan enzim dari dalam sel (Hardiningtyas 2009).

Steroid dapat dimanfaatkan sebagai sumber aprodisika alami yang merupan salah satu jenis hormon yang memiliki nilai ekonomis penting dalam industri farmasi sebagai aprodisiaka dan penambah vitalitas. Tritepenoid dapat dibagi atas empat golongan: triterpenoid, steroid dan glikosida (Harborne 1987). Komponen triterpenoid sebagian besarnya mempunyai kegiatan fisiologis yang menonjol, sehingga dalam kehidupan sehari-hari banyak dipergunakan sebagai obat misalnya pengobatan diabetes, gangguan kulit dan kerusakan hati.

\section{Aktivitas Antibakteri}

Hasil aktivitas antibakteri berdasarkan diameter zona hambat dari fraksi n-heksan, etil asetat dan n-butanol dari ekstrak metanol teripang kasur terhadap bakteri uji $S$. aureus, S. epidermilis, E. coli, P. aeruginosa dapat dilihat pada Tabel 2.

Pengujian aktivitas antibakteri terhadap bakteri S. epidermilis menunjukkan zona hambatyang lebih besar dari pada ketiga bakteri lainnya. Bakteri S. epidermilis termasuk dalam golongan bakteri Gram positif. Bakteri Gram positif cendrung lebih sensitif terhadap komponen antibakteri. Struktur dinding sel bakteri Gram positif berlapis tunggal yang relatif lebih sederhana sehingga memudahkan komponen untuk masuk ke dalam sel dan menemukan sasaran (Pelczar dan Chan 2010).

Hasil analisis menunjukkan bahwa aktivitas antibakteri maksimum dari 3 jenis fraksi yang digunakan ditunjukan oleh fraksi n-heksan pada kosentrasi $1.000 \mu \mathrm{g} / \mathrm{mL}$ ekstrak metanol teripang. Penelitian ini sejalan dengan hasil penelitian Aries et al. (2015) menyatakan bahwa kandungan komponen antibakteri yang terdapat pada fraksi n-heksan lebih dominan daripada fraksi lainnya, dengan nilai rata-rata zona hambat hampir mendekati $13 \mathrm{~mm}$, yang menunjukkan bahwa bahan uji pada fraksi tersebut berpotensi sebagai antibakteri.

Hasil aktivitas antijamur berdasarkan diameter zona hambat dari frakai n-heksan, fraksi etil asetat dan fraksi n-butanol dari ekstrak metanol teripang kasur terhadap jamur C. albicans dan T. mentagrophytes. Jamur C. albicans memiliki diameter zona hambat $11,07 \mathrm{~mm}$ dari fraksi $\mathrm{n}$-heksan pada kosentrasi $1.000 \mu \mathrm{g} / \mathrm{mL}$ memiliki aktivitas jamur lebih tinggi dibandingkan dengan $T$. mentagrophytes dengan zona hambat 11,00 $\mathrm{mm}$ dari fraksi etil asetat pada konsentrasi $1.000 \mu \mathrm{g} / \mathrm{mL}$.

Perbedaan struktur dinding sel antara bakteri dan jamur hal memberikan pertahanan yang lebih kuat terhadap sel jamur, sehingga sulit untuk komponen antimikroba yang terdapat pada ekstrak metanol teripang untuk merusak dinding sel jamur. Ekstrak metanol 
Tabel 2 Konsentrasi daya hambat minimun pada fraksi yang berbeda dari ekstrak metanol teripang kasur terhadap bakteri uji

(Table 2 The minimum inhibitory concentration of different fractions of methanol extract of sea cucumber on the test bacteria)

\begin{tabular}{|c|c|c|c|c|c|c|}
\hline \multirow{2}{*}{$\begin{array}{l}\text { Fraksi/ } \\
\text { Fraction }\end{array}$} & \multirow{2}{*}{$\begin{array}{l}\text { Bakteri uji/ } \\
\text { Bacterial test }\end{array}$} & \multicolumn{4}{|c|}{ Diameter zona hambat/ Inhibitory zone (mm) } & \multirow{2}{*}{$\begin{array}{c}\text { Kontrol/ } \\
\text { control } \\
\text { Kloramfenikol }\end{array}$} \\
\hline & & 250 & 500 & 750 & 1,000 & \\
\hline \multirow{4}{*}{ n-heksan } & S. aureus & $9.10 \pm 0.10$ & $9.56 \pm 0.05$ & $10.07 \pm 0.06$ & $11.00 \pm 0.00$ & 21.60 \\
\hline & S. epedremilis & $9.30 \pm 0.10$ & $9.63 \pm 0.06$ & $10.23 \pm 0.05$ & $12.26 \pm 0.05$ & 24.00 \\
\hline & E. coli & $8.63 \pm 0.05$ & $8.76 \pm 0.05$ & $9.43 \pm 0.00$ & $10.33 \pm 0.00$ & 22.40 \\
\hline & P. aeruginosa & $8.33 \pm 0.05$ & $8.83 \pm 010$ & $9.60 \pm 0.00$ & $10.97 \pm 0.00$ & 22.10 \\
\hline \multirow{4}{*}{ etil asetat } & S. aureus & $8.73 \pm 0.05$ & $9.33 \pm 0.07$ & $9.76 \pm 0.05$ & $10.13 \pm 0.05$ & 24.60 \\
\hline & S. epedremilis & $8.93 \pm 0.05$ & $9.56 \pm 0.05$ & $10.06 \pm 0.05$ & $11.73 \pm 0.05$ & 25.40 \\
\hline & E. coli & $8.27 \pm 0.01$ & $8.57 \pm 0.05$ & $8.90 \pm 0.00$ & $9.90 \pm 0.00$ & 22.30 \\
\hline & P. aeruginosa & $8.80 \pm 0.01$ & $9.53 \pm 0.05$ & $10.73 \pm 0.00$ & $10.83 \pm 0.00$ & 22.60 \\
\hline
\end{tabular}

Tabel 3 Konsentrasi hambat minimumfraksi yang berbeda dari ekstrak metanol teripang kasur terhadap jamur uji.

(Table 3 The Minimum inhibitory concentration (MIC) of different fractions of methanol extract of sea cucumber fungi test)

\begin{tabular}{llccccc}
\hline \multirow{2}{*}{$\begin{array}{l}\text { Fraksi/ } \\
\text { Fraction }\end{array}$} & \multicolumn{1}{c}{$\begin{array}{c}\text { Jamur uji/ } \\
\text { Fungi test }\end{array}$} & \multicolumn{3}{c}{$\begin{array}{c}\text { Diameter zona hambat }(\mathrm{mm}) / \text { Inhibitory zone } \\
(\mathrm{mm})\end{array}$} & $\begin{array}{c}\text { Kontrol/ } \\
\text { control }\end{array}$ \\
\cline { 3 - 5 } & & \multicolumn{3}{c}{ Kosentrasi/ concentration $(\mu \mathrm{g} / \mathrm{mL})$} & Nistatin \\
\cline { 3 - 6 } n-heksan & C. albicans & 6.00 & 8.60 & 9.00 & 9.77 & 16 \\
& T. mentagrophytes & 6.00 & 7.43 & 9.00 & 9.12 & 16 \\
\multirow{2}{*}{ etil asetat } & C. albicans & 6.00 & 6.00 & 10.70 & 11.00 & 16 \\
& T. mentagrophytes & 6.00 & 6.00 & 6.00 & 7.20 & 16 \\
& C. albicans & 6.00 & 6.00 & 6.00 & 10.93 & 16 \\
n-butanol & T. mentagrophytes & 6.00 & 6.00 & 6.00 & 6.00 & 16 \\
\hline
\end{tabular}

teripang tidak memberikan aktivitas dan tidak dapat membentuk terjadinya zona hambat terhadap jamur. Aktivitas antibakteri ekstrak metanol fraksi n-heksan S. vastus dengan kromatografi vakum cair $S$. vastus terhadap daya hambat minimum disajikan pada Tabel 4.

Perbedaan besarnya diameter zona hambat yang terbentuk pada masing-masing kosentrasi dapat disebabkan oleh adanya perbedaan besar kecilnya kandungan zat aktif antibakteri yang terkandung dalam fraksi n-heksan serta kecepatan difusi bahan antibakteri dalam medium agar. Uji fraksi n-heksan menggunakan kromatografi vakum cair pada aktivitas bakteri dengan kosentrasi berbeda menunjukkan bahwa aktivitas maksimum antibakteri yang paling baik pada kosentrasi $1.000 \mu \mathrm{g} / \mathrm{mL}$ ekstrak metanol teripang. Jenis jamur yang digunakan sebagai mikroba uji tidak menunjukkan aktivitas interaksi yang tinggi pada kosentrasi $1.000 \mu \mathrm{g} /$ $\mathrm{mL}$ ekstrak metanol teripang.

Konsentrasi hambat minimum tidak selalu konstan pada setiap komponen antibakteri yang diberikan. Nilai KHM dipengaruhi oleh beberapa hal, yaitu organisme uji, ukuran inokulum komposisi media kultur, waktu inkubasi serta kondisi inkubasi itu sendiri. Kondisi inkubasi yang mempengaruhi yaitu suhu, aerasi dan pH (Pelczar dan Chan 2008).

Pengujian aktivitas antimikroba terhadap jamur C. albicans dan T. mentagrophytes pada berbagai kosentrasi tidak menunjukkan 
Tabel 4 Fraksi n-heksan dengan kromatografi vakum cair terhadap aktivitas bakteri (Table 4 The $n$-hexane fraction with liquid vacuum chromatography on bacterialactivity)

\begin{tabular}{lccccc}
\hline \multirow{2}{*}{$\begin{array}{c}\text { Bakteri uji/ } \\
\text { Bacterial test }\end{array}$} & \multicolumn{4}{c}{ Dosentrasi /Concentration $(\mu \mathrm{g} / \mathrm{mL})$} & \multirow{2}{*}{ Kontrol/ Control } \\
\cline { 2 - 5 } & 250 & 500 & 750 & 1.000 & Kloramfenikol \\
\cline { 2 - 5 } & $9.10 \pm 0.10$ & $9.56 \pm 0.05$ & $10.07 \pm 0.06$ & $11.00 \pm 0.00$ & 17.60 \\
\hline S. aureus & $9.30 \pm 0.10$ & $9.63 \pm 0.06$ & $10.23 \pm 0.05$ & $12.26 \pm 0.05$ & 16.00 \\
S.epidermilis & $8.63 \pm 0.05$ & $8.76 \pm 0.05$ & $9.43 \pm 0.00$ & $10.33 \pm 0.00$ & 18.40 \\
E. coli & $8.33 \pm 0.05$ & $8.83 \pm 0.10$ & $9.60 \pm 0.00$ & $10.97 \pm 0.00$ & 17.10 \\
P.aeruginosa & & & & & \\
\hline
\end{tabular}

Tabel 5 Fraksi heksan dengan kromatografi vakum cair terhadap aktivitas antijamur (Table 5 The fraction $n$-hexane with liquid vacuum chromatography on antifungal activity)

\begin{tabular}{|c|c|c|}
\hline \multirow[t]{2}{*}{ Kosentrasi / Concentration $(\mu \mathrm{g} / \mathrm{mL})$} & \multicolumn{2}{|c|}{$\begin{array}{l}\text { Diameter zona hambat/ Inhibitory zone }(\mathrm{mm}) \\
\text { Jamur uji/ Fungal test }\end{array}$} \\
\hline & C. albicans & T. mentagrophytes \\
\hline 250 & 6.00 & 6.00 \\
\hline 500 & 7.63 & 7.41 \\
\hline 750 & 8.17 & 8.00 \\
\hline 1.000 & 9.77 & 9.12 \\
\hline Nistatin & 16 & 16 \\
\hline
\end{tabular}

aktivitas, jika dibandingkan dengan kontrol positif nistatin 100 UI yang memberikan daya hambat katagori sedang dengan diameter $16 \mathrm{~mm}$. Klasifikasi respon hambatan pertumbuhan, bahan uji yang digunakan tidak dapat menghambat pertumbuhan jamur karena stuktur dinding sel jamur yang kokoh. Dinding sel jamur terdiri dari membran sel jamur, untuk dapat merusak membrane sel jamur komponen-komponen metabolik sekunder harus dapat berikatan dengan ergosterol yang merupakan penyusun membrane sel, saat membentuk/berikatan dengan ergosterol maka akan terbentuk pori dan melalui pori tersebut konstituen esensial sel jamur misalnya ion $\mathrm{K}$, asam-asam karboksilat, asam amino dan esterfosfat keluar sehingga meyebabkan kematian sel jamur.

Perbedaan aktivitas masing-masing bahan uji terhadap bakteri dan jamur dapat disebabkan oleh perbedaan morfologi dari bakteri dan jamur. Sel bakteri memiliki marfologi dinding sel yang tersusun atas peptidoglikan sedangkan marfologi dinding sel jamur tersususun atas kitin. Kitin pada jamur berbentuk mikrofibril selulosa, yang merupakan struktur utama dinding sel jamur yang terdiri dari jalinan rantai-rantai polisakarida yang saling bersilang membentuk serabut paralel (Pratiwi 2008). Perbedaan aktivitas juga dapat dipengaruhi oleh perbedaan komposisi dan struktur dinding sel bakteri. Bakteri Gram positif memiliki lapisan peptidoglikan yang lebih tebal (20-80 $\mathrm{nm}$ ) sehingga pertahannya lebih kuat dan sulit untuk dirusak oleh komponen-komponen metabolik sekunder, sedangkan gram negatif yang memiliki lapisan peptidoglikan yang lebih tipis (5-10nm) akan lebih sensitif atau mudah dirusak oleh komponen-komponen metabolik sekunder yang mempunyai potensi merusak atau menghambat sintesis dinding sel. Jamur uji yang digunakan dalam penelitian ini yakni C. albicans dan T. mentagrophyes termasuk kelompok gram positif. 


\section{KESIMPULAN}

Ekstrak metanol teripang $S$. vastus mampu menghambat pertumbuhan bakteri $S$. epidermilis, $S$. aureus, $P$. aeruginosa dan E. coli. Zona hambat tertinggi ekstrak metanol terhadap bakteri S. epidermilis dan S. aureus yaitu 12,26 $\mathrm{mm}$ dan $11,00 \mathrm{~mm}$. Ekstrak metanol terhadap jamur C. albicans dan T. mentagrophytes yaitu $9,77 \mathrm{~mm}$ dan 9,12 $\mathrm{mm}$.

\section{UCAPAN TERIMAKASIH}

Penulis mengucapakan terimakasih kepada Direktorat Pendidikan Tinggi Kementerian Riset dan Teknologi dan Pendidikan Tinggi. Penelitian initelah didanai melalui Program Hibah Bersaing Tahun 2014. Penelitian ini merupakan bagian penelitian Hibah Bersaing tahun 2014.

\section{DAFTAR PUSTAKA}

Aditia RP, Desniar, Trilaksani W. 2018. Aktivitas antioksidan dan antibakteri hidrolisat protein hasil fermentasi telur ikan cakalang. Jurnal Pengolahan Hasil Perikanan Indonesia. 21(1): 1-12.

Aminin DL, Agafonova IG, Berdyshev EV, Isachenko EG, Avilov SA, Stonik VA, 2001. Immunomodulatory properties of Cucumariosides from the edible fareastern Holothurian Cucumaria japonica. Journal of Medical Food. 4(3): 127-135.

Aries T, Moalic Y, Serrao EA, Arnaud-Haond. 2015. Hologenome theory supported by cooccurrence networks of species specific bacterial communities in siphonous algae (Caulerpa). FEMS Microbiology Ecology. 91(7): 1-14.

Boyer RF. 1993. Modern Exprimental Biochemistry, $2^{\text {nd }}$ ed. Benjamin/Cummings publishing Company.

Fitrial Y. 2011. Aktivitas antibakteri ekstrak etil asetat biji teratai (Nymphaea pubescens Willd) akibat pemanasan. Jurnal Pengolahan Hasil Perikanan Indonesia. 15(1): 43-48.

Harborne JB. 2006. Metode Fitokimia: Penuntun Cara Modern menganalisis Tumbuhan. Edisi IV. Kokasih P. dan I. Soediro. (penterjemah). Bandung (ID): Institut Teknologi Bandung.
Hashimoto, Y., 1979. Marine toxin and other bioactive marine metabolites. Tokyo (JP): Japan Scientific Societies Press..

Haug T, Kjuu AK, Styrvold OB, Sandsdalen E, Olsen OM, Stensvag K. 2002. Antibacterial activity inStrongylocentrotus drobachieensis (echinoidea), Cucumaria frondosa (holothuroidea), and Asterias rubens (asteroidea). Journal of Invertebrate Pathology. 81: 94-102.

Ibrahim B, Suptijah P, Zahid A. 2012. Efektivitas kitosan mikrokristalin sebagai alternatif antibakteri alami dalam mouthwash. Jurnal Pengolahan Hasil Perikanan Indonesia. 15(2): 120-126.

Ivanov. 1998. Typhoid fever: Current and future control approaches. Medical Journal of Indonesia. 51: 81-85

Jawahar AT, Nagarajan J, Shanmugan SA. 2002. Antimicrobial substances of potential biomedical importance from holothurian species. Indian Journal of Marine Sciences. 31(2): 161-164.

Kaswandi MA, Lian HH, Nurzakiah S, Ridzwan BH, Ujang S, Samsudin MW, Jasnizat S,Ali AM. 2000. Crystal saponin from three sea cucumber genus and their potential as antibacterial agents. 9th Scientific Conference Electron Microscopic Society. 273-276.

Meydia, Suwandi R, Suptijah P. 2016. Isolasi komponen steroid dari teripang gama (Stichopus variegatus) dengan berbagai jenis pelarut. Jurnal Pengolahan Hasil perikanan Indonesia. 19(3): 363-369.

Moorthy K, Srinivasan K, Subramanian, Palaniswamy M, Mohanasundari C. 2007. Phytochemical screening and antibacterial evaluation of stem bark of Mallotus philippinensis var. Tomentosus. African Journal of Biotechnology. 6(13):1521-1523

Murray AP, Muniain C, Seldes AM., Maier M. 2001. Antifungal disulfated triterpene glycoside from the sea cucumber Psoulus patagonicus. Tetrahedron. 57: 9563-9568.

Pelczar MJ, Chan ECS. 2008. Dasardasar Mikrobiologi 1 Hadioetomo et al. Penerjemah. Jakarta (ID): UIPress Terjemahan dari: Elements of Microbiology. 
Pelczar MJ, Chan ECS. 2010. Dasardasar Mikrobiologi 2 Hadioetomo et al. Penerjemah. Jakarta (ID): UIPress Terjemahan dari :Elements of Microbiology.

Prihanto AA. 2012. Perbandingan aktivitas antibakteri Penicillium notatum ATCC 28089 dengan Penicillium sp. R1M yang diisolasi dari mangrove Sonneratia caseolaris. Jurnal Pengolahan Hasil Perikanan Indonesia. 15(1): 66-70.

Robinson T. 1995. Kandungan Organik Tumbuhan Tinggi. Edisi keenam. Padmawinata $\mathrm{K}$, penerjemah. Bandung (ID) : ITB. Terjemahan dari: The organic Constituents of Higher Plant.

Rochima E, Fiyanih E, Afrianto E, Joni IM, Subhan U, Panatarani C. 2018. Efek Penambahan suspensi pada edible coating terhadap aktivitas antibakteri. Jurnal Pengolahan Hasil Perikanan Indonesia. 21(1): 127-136.

Setyaningsih I, Pangabean LM, Riyanto B, Nugraheny N. 2006. Potensi antibakteri diatom laut (Skeletonema costatum) terhadap bakteri Vibrio sp. Buletin Teknologi Hasil Perikanan. 9(1): 61-71.

Kustiariyah. 2007. Teripang sebagai sumber pangan dan bioaktif. Buletin teknologi Hasil Perairan. 10(1): 1-8

Tarman K, Purwaningsih S, Negara AAAPPN. 2013. Aktivitas Antibakteri ekstrak daun bakau hitam (Rhizophora mucronata) terhadap bakteri penyebab diare. Jurnal Pengolahan Hasil Perikanan Indonesia. 16(3): 249-258.

Tirtodiharjo MK. 2011. Strategi mengatasi bacteria yang resisten terhadap antibiotika. Pidato Pengukuhan Jabatan Guru Besar Fakultas Farmasi Universitas Gadjah Mada tanggal 22 Desember 2011. Yogyakarta (ID): Universitas Gadjah Mada.

Van den Bergh ET, Gasem MH, Keuter M, Dolmans MV. 1999. Out come in three group of patient with typhoid fever in Indonesia betweent 1948-1990. Tropical Medicine and International Helath. 4: 211-215.

Von Nussbaum, F, Brands M, Hinzen B, Weigand S, Habich D. 2006. Antibacterial natural products in medical chemistryexodus or revival. A Journal of the Geselleschaft Deutscher Chemiker. 45: 5072-5129.

Weliyadi E, Awaludin, Imra, Maulianawati D. 2018. Aktivitas antibakteri ekstrak daging kerang bakau (Gelonia Coaxans) dari kawasan magrove tarakan terhadap Vibrio parahaemolyticus. Jurnal Pengolahan Hasil Perikanan Indonesia. 21(1): 35-41.

Zheng I, Chen H, Han X, Lin W, Yan X. 2005. Antimicrobial screening and active compound isolation from marine bacterium NJ6-3-1 associated with the sponge Hymeniacidon perleve. World Journal of Microoganism and Biotechnology. 21: 201-206. 